\title{
NEGOTIATION OF MEANING: STUDENTS' AWARENESS OF THEIR MISTAKES IN USING ENGLISH FOR THE SECONDARY SCHOOL LEVEL
}

\author{
Ferayani Ulrica \\ Universitas Lampung \\ ulricaferayani@gmail.com
}

Received: 12 May $2020 \quad$ Accepted: 23 June 2020

Published: 31 July 2020

\begin{abstract}
In traditional classes, teachers teach grammar in a deductive way with meaningless activities. The activities do not emphasize the uses of English in real life and lack of communication among teachers and students. Language awareness might give the students a challenge to pose questions and encourage them to explore themselves on how language works. The teachers might be able to encourage the students to participate to lead them to get communicative skills by using negotiation of meaning. This article is intended to explore and analyze the students' mistakes when negotiating meaning in the language learning process. The qualitative descriptive research was employed in this study with 33 students in senior high school as the subjects of the research. The data were from the students' interviews and recordings. The finding revealed that the students produced mistakes in grammar, pronunciation, and vocabulary. It showed that the extent of the students' awareness in responding to a mistake in the negotiation of meaning was low. It was only 16 incorrect utterances that might be corrected by the students. It was divided into two sides, willingness and unwillingness to correct. Factors were affecting the students not to be aware during interaction such as focusing on meaning, the same proficiency level, and condition of the class.
\end{abstract}

Keywords: negotiation of meaning, teach grammar, language awareness.

\section{To cite this article:}

Ulrica, F. (2020). Negotiation of Meaning: Students' Awareness of Their Mistakes in Using English for the Secondary School Level. Journal of Research on Language Education, 1(1), 1-5.

\section{INTRODUCTION}

Language awareness refers to the action of sensitivity and conscious awareness of the nature of language and its role in human life. In a language learning process, students' language awareness plays an important role to help the students to construct their grammar mastery from their exploration and trial tasks. Language awareness might challenge students to pose questions and explore how language works. Thus, they enable to notice and learn how a grammar feature works. Language awareness appears due to the existence of an interaction between teacher and students or vice versa. Here, interaction gets an important role for creating successful interactive systems (Sari, 2018) to achieve communicative process by exchanging the thought and feelings (Brown, 2000) and sharing the information and knowledge in a language classroom (Rido \& Sari, 2018).

During the interaction, the students are expected to achieve comprehensible input to improve their English skills. On the contrary, when the interaction process is running, the utterances express by one party of speakers often cannot be understood by the listener so a misunderstanding of information conveyed may consequently occur. To avoid repetitive situations, language instructors or teachers might encourage the students to use one of the communication strategies namely negotiation of meaning. By using the negotiation of meaning, it allows students to make communication more effective. Unfortunately, there is no guarantee that interaction between native and non-native speakers by using negotiation of meaning can be comprehensible. During the interaction, students focus more on meaning. In other words, they do not pay attention or aware of the accuracy at the language components, such as structure and vocabulary.

In the classroom, most students may use particular learning strategies and learning styles to reach language learning objectives (Ayu, 2018; Mandasari \& Oktaviani, 2018; Lestari \& Wahyudin, 2020; Wahyudin \& Rido, 2020) to support language learning process (Putri \& Sari, 2020). On the other hand, according to Ayu (2018), teachers' goal in the classroom is to deal with students by controlling the activities and provide their students a 
widest opportunity to improve their skills and potentialities at the optimum level. As a fact that teacher's style in teaching grammar mostly uses the traditional method such as an explanation in a deductive way by providing meaningless activities. The teacher does not encourage students to use English with proper communication skills in the class. As a result, the students have an inadequacy to use communication skills since they tend to train themselves to create the correct sentences with the right grammar rule without knowing the message conveyed (Lin, 2011). Thus, the purposes of this study are to explore the students' mistakes when negotiating meaning and analyze the students' awareness of the mistake when negotiating meaning in the language learning process.

\section{RESEARCH METHOD}

A case study was employed in this present study. By recording and interviewing 33 students, the writer explored the students' awareness of mistakes in the negotiation of meaning. The information gap activity was implemented in the class to stimulate the students in producing the negotiation of meaning. The interaction of students was recorded, transcribed, analyze their mistakes based on three language components such as structure, pronunciation, and vocabulary. The mistake's criteria made by the students were divided into five levels: $0 \%-20 \%$ indicates a very low level; $21 \%-40 \%$ indicates a low level; $41 \%-60 \%$ indicates average level; $61 \%-80 \%$ indicates high level; $81 \%-100 \%$ indicates very high level.

Semi-structured interviews with open-ended questions were used to interview students. The students were allowed to express their opinions on their terms. The interview process was based on the students' utterances and their comprehensible input during the negotiation of meaning. Besides, the students' awareness was observed and categorized into two terms, i.e., willingness to correct and unwillingness to correct. The writer valued the students' comprehensible input based on the wrong utterance that could be corrected by the students during their talk.

\section{FINDINGS AND DISCUSSION}

The present study aimed at exploring and analyzing the students' mistakes when negotiating meaning in the language learning process. The findings of this study were displayed into two sub-sections. First, the subsection was about the students' mistakes in the three language aspects, including grammar, pronunciation, and vocabulary. Based on the findings, most students were indicated making mistakes during the language learning process, especially in the language aspects - structure, pronunciation, and vocabulary. The detail was displayed in table 1, as follows:

Table 1. Students' Mistake in the Language Aspects

\begin{tabular}{cccc}
\hline \multirow{2}{*}{ Group } & \multicolumn{3}{c}{ Language Aspects } \\
\cline { 2 - 4 } & Structure & Pronunciation & Vocabulary \\
\hline 1 & 2 & 1 & 0 \\
2 & 1 & 0 & 0 \\
3 & 1 & 1 & 0 \\
4 & 3 & 1 & 0 \\
5 & 1 & 1 & 0 \\
6 & 7 & 1 & 1 \\
7 & 8 & 0 & 3 \\
8 & 2 & 2 & 0 \\
9 & 5 & 0 & 0 \\
10 & 1 & 0 & 0 \\
11 & 5 & 0 & 0 \\
12 & 0 & 1 & 0 \\
13 & 2 & 0 & 0 \\
14 & 0 & 0 & 0 \\
15 & 0 & 0 & $\mathbf{5}$ \\
16 & 2 & 1 & $\mathbf{9 \%}$ \\
Frequency & $\mathbf{4 0}$ & $\mathbf{9}$ & $\mathbf{1 7 \%}$ \\
\% & $\mathbf{7 4 \%}$ & &
\end{tabular}

Table 1 showed that the language aspect of the structure was the highest frequency of students' mistakes with a total of 40 points or $74 \%$. The language aspect of pronunciation was in second place with a total of mistakes $17 \%$ (9 points). The lowest frequent mistake was vocabulary with a total of 5 points (9\%).

In the structure, the students made a lot of mistakes in using to be by omitting to be when there was no verb in the sentence. It was called the nominal sentence (non-verbal), for example: How you opinion? What the film? How the price of the film?, etc. Another extract showed the students' mistake in structure, as follows:

B "There is 4 movies show on this day."

A "What are those?" 
Journal of Research on Language Education (JoRLE), Vol: 1, No: 1, 1-5

This incorrect utterance showed that the student was confused in using is and are in the plural sentence. The hearer was not aware of correcting the mistake during the interaction. There was no correction and he continued the conversation without paying attention to that mistake. From the interview in this group, it can be concluded that the hearer had the ability in giving an input to the speaker but he did not focus on the utterance so the speaker did not get any comprehensible input.

The students also made mistakes because their first language influenced the pronunciation of the target language. Some students had difficulty with English sounds because they were deeply influenced by similar Indonesian sounds. It could be seen from the examples; Aktually, it's my first time, I don't like the oktor, It's a good idea, etc. Besides, in the language aspect of vocabulary, the students lacked vocabulary mastery, so they had a limited capacity to understand in other skills of English and could not communicate with others clearly in the English language. To avoid misunderstanding, they sometimes changed the word into Indonesian, for instance, $I$ really want because I'm penasaran.

The second sub-section was about students' awareness. According to the data, the students' awareness in responding to the mistakes during the negotiation of meaning was low. The result was displayed in table 2:

Table 2. Students' Awareness

\begin{tabular}{|c|c|c|c|c|}
\hline \multirow[b]{2}{*}{ Group } & \multirow[b]{2}{*}{ Mistake } & \multicolumn{2}{|c|}{ Awareness } & \multirow[b]{2}{*}{ Unawareness } \\
\hline & & $\begin{array}{l}\text { Willingness to } \\
\text { correct }\end{array}$ & $\begin{array}{c}\text { Unwillingness to } \\
\text { correct }\end{array}$ & \\
\hline 1 & 3 & 1 & 0 & 2 \\
\hline 2 & 1 & 0 & 0 & 1 \\
\hline 3 & 2 & 0 & 0 & 2 \\
\hline 4 & 4 & 0 & 0 & 4 \\
\hline 5 & 2 & 0 & 1 & 2 \\
\hline 6 & 9 & 1 & 0 & 8 \\
\hline 7 & 11 & 4 & 3 & 4 \\
\hline 8 & 4 & 0 & 1 & 3 \\
\hline 9 & 5 & 0 & 1 & 4 \\
\hline 10 & 1 & 0 & 0 & 1 \\
\hline 11 & 5 & 0 & 0 & 5 \\
\hline 12 & 1 & 1 & 0 & 0 \\
\hline 13 & 3 & 0 & 1 & 2 \\
\hline 14 & 0 & 0 & 0 & 0 \\
\hline 15 & 0 & 0 & 0 & 0 \\
\hline 16 & 3 & 0 & 2 & 1 \\
\hline Frequency & 54 & 7 & 9 & 38 \\
\hline$\%$ & $100 \%$ & \multicolumn{2}{|c|}{$30 \%$} & $70 \%$ \\
\hline
\end{tabular}

Table 2 showed that the total mistake was 54 points. The students were aware of 16 incorrect utterances (30\%). It was divided into two categories; willingness to correct and unwillingness to correct. There were 7 incorrect utterances that willing to be corrected by the students while 9 utterances were not corrected even the students knew the incorrect utterances occurred during the interaction. The rest, 38 utterances $(70 \%)$ were not corrected because the students were not aware their interlocutor made mistakes during the interaction. After doing an interview, the researcher found that some students noticed the incorrect utterances but they were reluctant to correct them in the dialogue since they still got the meaning of the message.

To see the extent of student's awareness in a mistake during negotiation of meaning and their comprehensible input, it would be elaborated in the following extracts:

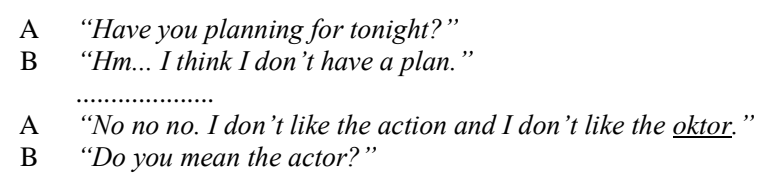

From the extracts above, The ungrammatical utterance made by student $\mathrm{A}$ in this group was not be corrected by student B. The hearer responded the question correctly but she did not realize that the speaker's utterance was wrong. Based on the interview, student B could not correct the sentence because she also did not know the correct one. This utterance was corrected by the interlocutor. Students B got the meaning even though students A said in the wrong pronunciation. Based on the interview, the speaker knew how to say actor. She said oktor spontaneously because she was influenced by Indonesian sounds "aktor".

Based on the findings, there were two propositions: (1) the students made mistakes in structure/grammar, pronunciation, and vocabulary; and (2) students' awareness of their mistakes was low during the negotiation of meaning. It was found that most students participate and engaged actively during the language learning process. They created a pair of dialogues following the instruction from the teacher. They did group work tasks in which they work together with their partners, share their ideas, learn from each other, fell more secure and less anxious, and enjoy using English to communicate (Jones, 2007). The implication of why students were not aware of the 
mistake is because the spoke spontaneously. The learners did not realize the mistake since they still got the message of the utterances. They were not aware of the language components of the sentence, such as grammar, pronunciation, and vocabulary. It also was difficult for many students to respond when they were asked to say something in a foreign language because they might have little ideas about what to say, which vocabulary to use, or how to use the grammar correctly (Baker \& Westrup cited in Tuan \& Mai, 2015).

A grammar form might be difficult to learn if (a) it contained non-essential communicative meaning, (b) its use was optional, and/or (c) its form meaning relationship was obscure. Learners learned a grammar form that fits any of these criteria may experience problems of form-meaning mapping. To illustrate, learning the English verb inflection particularly difficult for L2 learners whose L1s did not have an equivalent form. The students might have different proficiency levels. By language awareness, students could collaborate and helped each other to understand grammar. Language awareness aimed at helping learners to discover the use of language to acquire readiness for it, and to know about language instead of enabling them to perform a structure correctly (Tomlinson, in Restrepo, 2006).

Furthermore, the incorrect pronunciation was often caused by the lack of sound similarity between English and the students' native language. The learner's first language influenced the pronunciation of the target language and it was a significant factor in accounting for foreign accents. Samigan (2015) stated that Indonesian speakers of English had problems resulting from L1 (first language) interference. Some students in this research tend to have difficulty with English sounds because they are deeply influenced by similar Indonesian sounds. several factors needed to be considered to be potential obstacles for a foreign language learner through the acquisition of correct pronunciation. Those factors could be age factor, phonetic ability, lack of practice, motivation, personality or attitude, and mother tongue. (Riswanto \& Haryanto, 2012). On the other hand, Learning pronunciation was difficult because, by the time the learners are introduced to the second language sound system, they had a fossilized sound system of their mother tongue, which hinders the acquisition of the L2 sound system. They were still difficult to differentiate between pronouncing vowels and consonants. It was caused by pronouncing vowels and consonants between Indonesian and English which were different, so sometimes it made them confused to pronounce vowels and consonants in English.

The more people master vocabulary the more they can speak, write, read, and listen as they want. Wilkins in Al-Khasawneh (2012) stated that without grammar very little could be conveyed, without vocabulary nothing could be conveyed. It meant that even someone had good grammar but it would be useless if they did not know many vocabularies. Besides, it was supported by Ur in Rohmatillah (2014) that vocabulary was one of the important things to be taught in learning a foreign language because it would be impossible to speak up without a variety of words.

Moreover, the students hopefully developed their awareness to get involved actively in the process of teaching and learning. They hopefully might notice the types and amount of differences between the languages they used and the language an interlocutor used, and notice their gap between their intended content of the speech and their ability in expressing it, due to their lack of language knowledge. So, the interaction could also draw learners' attention to something new, such as a new vocabulary, grammatical item, or pronunciation. Before doing the task, the researcher instructed the student to help their friend who faced the problem by giving correction. Kawaguchi (2012) claimed that the purpose of providing such corrective instruction was to draw L2 learners' attention to their non-target like production and assist their L2 learning. From the result, it could be concluded that many students in this research ignored the researcher's instruction to be aware of the mistake. In this study, students' awareness of mistakes that willing to be corrected during the negotiation of meaning was low. The research findings showed that most of the students in this research did not pay attention to his/her friend's mistake during the interaction. The majority of participants failed to notice half or more of the target language formulas in the interaction. These findings seem largely in keeping with the claim from Guz (2014) that learners had an underdeveloped and ill-conceived sense of collocation and were unaware of the strong lexical bonds that exist among many English words.

\section{CONCLUSION}

It can be concluded that all of the students actively involved the activity. During the interaction, they made many mistakes in language components, such as grammar, pronunciation, and vocabulary. Based on the observation from the task that had been done by the researcher, grammar became the highest frequency mistake with $74 \%$. The second place was pronunciation with $17 \%$. The last was vocabulary with $9 \%$. The students hopefully developed their awareness to participate actively in the process of learning. However, the result of this research showed that students' awareness of mistakes that willing to correct in this research was low. Most of them did not pay attention to the mistakes. Students were aware of 16 incorrect utterances $(30 \%)$. It was divided into two sides; willingness and unwillingness to correct. There were 7 incorrect utterances that willing to be corrected 
Journal of Research on Language Education (JoRLE), Vol: 1, No: 1, 1-5

by the students while 9 utterances were not corrected even the students knew the incorrect utterances occurred during the dialogue. The rest, 38 incorrect utterances (70\%) were not corrected during the interaction because the learners were not aware of the mistakes made by their interlocutor. Then, from the utterances that corrected, only 4 utterances became an input for the students. It happened because of some reasons, such as the learners focused more on conveying meaning, and they were in the same language proficiency level. The condition of the class also influenced the result of this research.

\section{REFERENCES}

Al-Khasawneh, F. M. (2012). Vocabulary Learning Strategies: A Case of Jordan University Of Science And Technology. English for Specific Purposes World, 34(12), 1-15.

Ayu, M. (2018). Interactive Activities for Effective Learning in Overcrowded Classrooms. Linguists: Journal of Linguistics and Language Teaching, 4(2), 1-6.

Baker, J., \& Westrup, H. (2003). Essential Speaking Skills: A Handbook for English Language Teachers. London: Continuum.

Brown, H. D. (2000). Teaching by Principles: An Interactive Approach to Language Pedagogy (2nd Edition). New York: Pearson Education.

Guz, E. (2014). Gauging Advanced Learners' Language Awareness: Some Remarks on the Perceptual Salience of Formulaic Sequences. Awareness in Action. Switzerland: Springer International Publishing.

Jones, L. (2007). The Student-Centered Approach. New York: Cambridge University Press.

Kawaguchi, S. \& Ma, Y. (2012). Corrective Feedback, Negotiation of Meaning and Grammar Development: Learner-Learner and Learner-Native Speaker Interaction in ESL. Open Journal of Modern Linguistics, 2(2), 57-70.

Lestari, M. \& Wahyudin, A. Y. (2020). Language Learning Strategies of Undergraduate EFL Students. Journal of English Language Teaching and Learning, 1(1), 25-30.

Lin, Y. (2011). A Language Awareness Approach to English Language Teaching in Joint Programs in China. Proceedings of the 16th Conference of Pan-Pacific Association of Applied Linguistics, 123-128.

Mandasari, B. \& Oktaviani, L. (2018). English Language Learning Strategies: An Exploratory Study of Management and Engineering Students. Premise: Journal of English Education and Applied Linguistics, 7(2), 61-78.

Putri, E. \& Sari, F. M. (2020). Indonesian EFL Students' Perspectives towards Learning Management System Software. Journal of English Language Teaching and Learning, 1(1), 20-24.

Restrepo, A. I. (2006). Implementing a Language Awareness Approach to Grammar Through Topics. Medellin: Universidad de Antioquia.

Rido, A. \& Sari, F. M. (2018). Characteristics of Classroom Interaction of English Language Teachers in Indonesia and Malaysia. International Journal of Language Education, 2(1), 40-50. DOI: http://dx.doi.org/10.26858/ijole.v2i1.5246

Riswanto \& Haryanto, E. (2012). Improving Students' Pronunciation through Communicative Drilling Technique at Senior High School (SMA) 07 South Bengkulu, Indonesia. International Journal of Humanities and Social Science 2(21).

Rohmatillah. (2014). A Study on Students' Difficulties in Learning Vocabulary. Lampung: IAIN Press.

Samigan, A. (2016). First Language Interference in EFL Students' Composition of IAIN Salatiga. Salatiga: Muhammadiyah Univerisity of Surakarta Press.

Sari, F. M. (2018). Patterns of Teaching-Learning Interaction in the EFL Classroom. Teknosastik: Jurnal Bahasa dan Sastra, 16(2), 41-48.

Tuan, N. H. \& Mai, T. N. (2015). Factors Affecting Students' Speaking Performance at LE Thanh Hien High School. Asian Journal of Educational Research, 3(2), 8-23.1

Wahyudin, A. Y. \& Rido. A. (2020). Perceptuals learning styles preferences of international master's students in Malaysia. BAHTERA: Jurnal Pendidikan Bahasa Dan Sastra, 19(1), 95-103. https://doi.org/10.21009/bahtera.191.10.

\section{BIOGRAPHY OF AUTHOR}

Ferayani Ulrica studied in the English Department, the Faculty of Teacher Training and Education, Universitas Lampung. She received her Master's Degree in 2017. She is an English teacher in one of the Senior High School in Bandar Lampung. 